\title{
CERITA SEJARAH DAN PENANAMAN NILAI-NILAI MORAL (STUDI KASUS DI DESA PANDEAN KECAMATAN MEJAYAN KABUPATEN MADIUN)
}

\author{
Ari Frianti Ristiana \& Soebijantoro*
}

\begin{abstract}
Abstrak
Penelitian ini bertujuan untuk menanamkan nilai-nilai moral dari pesan yang ada dalam cerita kepada anak-anak usia dini antara 1-6 tahun di Desa Pandean sehingga selain membacakan cerita, para orangtua di Pandean juga mendidik anak-anak mereka dengan cerita. Cerita bisa mendorong minat baca anak untuk membaca khususnya anak usia dini, sehingga dengan membaca cerita anak juga bisa mengimplementasikan pesan moral yang ada dalam cerita di lingkungan belajarnya. Selain itu, penelitian ini dapat bermanfaat untuk dijadikan bahan ajar oleh orangtua atau para tenaga pendidik kepada siswanya, dan menjadi metode dalam mendidik anak-anak pada usia dini.

Penelitian ini mengambil tehnik sampel purposive karena bertujuan untuk mengambil data dari sebagian populasi TK yang ada di Pandean. Hal ini dimaksudkan untuk mempermudah dalam pengambilan sampel yang lebih efisien dan efektif. Penelitian ini menggunakan angket yang disebarkan kepada ibu-ibu di TK Pembina. Peneliti menyebarkan angket dan 30 menit kemudian data dari angket tersebut dikumpulkan dan diteliti secara cermat dan tepat apakah ada kekurangan dalam pengumpulan data. Penelitian ini juga dilakukan bagi ibu-ibu di sekitar Pandean yang mempunyai anak umur 1-6 tahun. Selain itu, peneliti menggunakan metode observasi kepada anak-anak dalam penelitian ini.

Hasil penelitian menunjukkan bahwa dari 627 KK di Kelurahan Pandean yang mempunyai anak antara usia 1-6 tahun yaitu $73 \mathrm{KK}$, dan peneliti mengambil data sebanyak 50\% dari ibu-ibu di Pandean telah membacakan cerita sejarah atau cerita dongeng kepada anaknya baik itu sebelum tidur atau di waktu senggang. Dari 36 responden, terdapat 26 responden yang membacakan cerita untuk anak-anaknya. Jadi hanya 35\% orangtua di Pandean yang membacakan cerita untuk anaknya. Tujuan para orangtua untuk membacakan cerita sejarah ini kepada anak agar anak memiliki wawasan luas tentang dunia nyata, anak akan mempunyai imajinasi dengan bercerita, mendorong anak untuk belajar membaca buku dari usia dini, dan menanamkan nilai-nilai luhur dalam cerita sejarah/dongeng. Menurut para orangtua di Pandean, mereka berusaha untuk meluangkan waktu untuk membacakan cerita bagi anak-anak mereka walaupun mereka sibuk baik di rumah dan di luar rumah. Sebagian besar orangtua di Pandean membacakan cerita rakyat Malin Kundang kepada anak mereka karena di dalam cerita Malin Kundang terdapat nilai luhur bagi anak usia dini yaitu tidak boleh durhaka kepada orangtua, sayang kepada orangtua, bekerja keras jika ingin berhasil.
\end{abstract}

Kata Kunci: Nilai, Moral, Anak, Cerita Sejarah

Pendahuluan

Indonesia merupakan bangsa

yang multikulturalisme, dalam

kemajemukan tersebut di setiap suku

bangsa terdapat cerita yang mewarnai

kehidupan masyarakatnya. Cerita tersebut tidak lepas dari kejadian masa lampau yang terjadi pada manusia. Cerita bisa dihubungkan dengan sejarah karena sejarah memiliki bahan dasar cerita. Dudung Abdurrahman (1999:1) berpendapat bahwa sejarah sebagai 
kisah atau cerita merupakan makna yang subjektif, yakni peristiwa masa lalu yang telah menjadi pengetahuan manusia.

Dalam kehidupan sehari-hari kita sering mendengar cerita tentang peristiwa di dalam lingkungan tempat tinggal. Cerita bisa dijadikan bahan ajar dan pendidikan bagi anak-anak di usia dini agar mengetahui cerita di lingkungan tempat tinggal mereka. Anak-anak bisa melihat, merasakan, menelaah, mendengar apa yang mereka ketahui. Tadkiroatun Musfiroh (2011:45) berpendapat bahwa sejarah yang disajikan dalam bentuk cerita memiliki efektivitas yang sulit ditandingi oleh metode lain. "Perkataan sejarah dalam bahasa Indonesia adalah sama dengan "history" dari bahasa Inggris. Sejarah juga berasal dari kata benda Yunani yaitu "istoria". Menurut definisi umum, kata "history" berarti masa lampau manusia" (Louis Gottschalk, 1969:27).

Tadkiroatun Musfiroh (2011:47) menyebutkan bahwa sejarah terkait dengan cerita, karena sejarah adalah salah satu dari bahan cerita dan cerita adalah salah satu cara menyajikan sejarah. Cerita sejarah mempunyai dua bentuk yaitu bentuk umum dan bentuk khusus:
1. Bentuk umum yaitu penyusunan fakta-fakta menurut bentukan waktu dengan memberikan tafsiran berdasarkan suatu pandangan sejarah tertentu. Cerita sejarah pada umumnya disusun secara demikian, yakni sebuah cerita yang mempunyai arah gerak sejarah tertentu.

2. Bentuk khusus yaitu bentuk biografi. Biografi adalah riwayat hidup seseorang, manusia. Dalam istilah sejarah maka biografi adalah riwayat hidup tokoh-tokoh sejarah yang penting (R. Moh. Ali, 2005:197).

Garraghan (dalam Dudung Abdurrahman, 2007:47) menyebutkan bahwa penyebaran cerita-cerita sejarah disebarkan melalui tradisi lisan yang isinya samar-samar tetapi penuh arti (significant) melalui tiga jenjang: Pertama, tersebar melalui cerita yang disampaikan oleh bapak/ibu kepada anaknya, dari guru kepada muridnya. Kedua, cerita sejarah diperkenalkan dalam adat istiadat, kebiasaankebiasaan. Ketiga, cerita sejarah diabadikan dalam tulisan dan bentukbentuk gambar. Cerita sejarah itu dapat dikelompokkan menjadi dongeng (tale), legenda (legend), mite (myth), fable (fable) dan sage (Dudung Abdurrahman, 2007:47). 
Cerita-cerita sejarah sangat menarik untuk dibacakan kepada anak usia dini. Misalnya; cerita sejarah tentang Roro Jonggrang, Cinderella, Bawang Merah dan Bawang Putih, Kancil Nyolong Timun, Asal-usul kota Banyuwangi, Kolor Ijo dan lain-lain. Dengan membacakan cerita maka anak akan dirangsang cara berpikir, cara melihat suatu masalah, cara menangkap pesan-pesan moral yang ada dalam cerita tersebut. Dalam membacakan cerita-cerita itu, para orangtua harus bisa membacakan dengan meniru gerakan, suara, mimik muka agar anak merasa dirinya berada dalam dunia cerita yang dibawakan oleh para orang tua. Nilai-nilai moral yang terkandung di dalam cerita merupakan sebuah nasihat atau pesan moral agar anak bertingkah laku baik seperti tokoh yang ada di cerita dan mereka diberi arahan agar tidak meniru hal-hal yang tidak baik dilakukan seperti tokoh jahat yang ada di dalam cerita. Anak-anak di usia dini perlu perhatian dan tanggungjawab orangtua karena dengan menyayangi, membelai, mencintai dan memberikan perhatian penuh maka anak akan merasa dirinya dihargai dan diberi kasih sayang penuh. Dengan demikian, hubungan yang erat akan tercipta melalui kedekatan antara ibu dan anak.
Cerita-cerita sejarah dapat menanamkan nilai-nilai kepada anak tentang apa itu bekerja sama, gotong royong, saling menolong, pemberani dan lain sebagainya. Dengan membacakan cerita, maka akan menyampaikan langsung kepada anak tentang pesan atau nasihat apa saja yang ada dalam cerita-cerita sejarah sehingga anak dengan mudah menangkap apa yang dimaksudkan oleh orangtua mereka. Selain itu, dengan sering membacakan cerita kepada anak, maka anak akan terdorong untuk membaca buku dan menerapkan apa saja yang disampaikan orangtua mereka. Anak-anak akan mengetahui baik dan buruknya suatu masalah, mereka senantiasa dibiasakan untuk berpikir untuk menghadapi suatu keadaan dalam penglihatan mereka. Nilai-nilai positif disini berhubungan dengan kehidupan sehari-hari. Nilainilai ini juga mengacu pada nilai-nilai luhur Pancasila yang tercantum pada sila pertama hingga sila kelima. Akan tetapi di era modern ini, budaya bercerita atau mendongeng yang dulu menjadi pengantar tidur anak telah mengalami degradasi yang cukup mengkhawatirkan. Kini, istilah mendongeng ini sudah menjadi sesuatu yang sangat asing dan tidak menarik lagi bagi seorang anak. 
Bahkan sekarang ini, anak-anak menikmati cerita yang belum saatnya mereka nikmati dan cerita tersebut patut menjadi renungan semua pihak. Cerita memiliki dua sisi yang bertentangan. Satu sisi, mengisi daftar metode mendidik yang menyenangkan, satu sisi lain mengisi daftar perusak karakter manusia (Tadkiroatun Musfiroh, 2011:46). Cerita di TV yang sekarang ini marak dipertontonkan yaitu sinetron yang tidak bermutu,

\section{Tujuan dan Manfaat Penelitian}

Tujuan penelitian ini adalah untuk mendapatkan data tentang fenomena yang terjadi pada masa sekarang yaitu apakah metode bercerita masih diterapkan oleh para orangtua di Pandean, sedangkan yang kita tahu sekarang ini banyak media yang lebih menarik daripada mendengarkan cerita. Padahal dengan bercerita dapat menerapkan nilai-nilai luhur yang ada dalam cerita tersebut. Selain itu, tujuan penelitian ini adalah untuk menerapkan nilai-nilai moral yang ada dalam cerita Malin Kundang kepada anak-anak usia 1-6 tahun dan untuk mengetahui apakah para orangtua di Desa Pandean masih membudayakan metode bercerita kepada anak-anaknya.

Hasil penelitian ini diyakini dapat bermanfaat bagi beberapa pihak, yaitu: reality show, tontonan untuk orang dewasa. Oleh karena itu peneliti tertarik untuk mengadakan penelitian tentang bercerita cerita sejarah yang dapat menanamkan nilai-nilai moral kepada anak agar anak dapat mengambil pesan moral yang ada pada cerita tersebut serta untuk meneliti apakah cerita sejarah perlu dibudayakan para orangtua di Kelurahan Pandean di era teknologi yang serba canggih sekarang ini.

1. Bagi Prodi Pendidikan Sejarah FPIPS IKIP PGRI Madiun

Sebagai bahan wacana untuk mahasiswa prodi pendidikan sejarah agar tergerak untuk membaca cerita-cerita sejarah serta mengambil nilai-nilai positifnya.

2. Bagi Masyarakat

Sebagai bahan masukan kepada para ibu-ibu untuk mengenalkan kepada anak tentang cerita sejarah yang menarik dan dapat mengambil nilai-nilai luhur yang ada dalam cerita tersebut.

3. Bagi Pemerintah

Diharapkan dapat memberikan sumbangsih yang nyata kepada masyarakat agar mereka lebih menghargai tentang penanaman bercerita cerita sejarah di daerahnya sendiri. 


\section{Tinjauan Pustaka}

\section{A. Cerita Sejarah}

\section{Pengertian Cerita}

Menurut Kamus Umum Bahasa Indonesia yang dimaksud dengan cerita adalah tuturan yang membentangkan bagaimana terjadinya sesuatu peristiwa, kejadian, karangan yang menuturkan perbuatan atau pengalaman atau penderitaan orang (Poerwadarminta, 1984:202).

Apa yang dimaksud dengan cerita, bukan hanya cerita seperti yang kita batasi sekarang. Cerita memiliki dunia yang sama luas dengan dunia itu sendiri. Apapun yang ada di dunia ini tidak lepas dari cerita (Tadkiroatun Musfiroh, 2011:46).

Cerita dapat mengemukakan apa itu sejarah sedangkan sejarah juga dapat mengintrepretasikan cerita-cerita yang mengandung nilai-nilai moral di dalamnya. Cerita yang bersifat sejarah seperti babad, tambo, dan silsilah serta dongengdongeng atau cerita setempat dapat terangkum di dalam pengertian sastra secara luas. Dongengdongeng atau cerita setempat ini sering disebut sastra lisan. Suatu kenyataan bahwa naskah-naskah lama yang disebut dengan nama "sejarah" sering mengungkapkan peristiwa-peristiwa kesejarahan dengan jalinan cerita-cerita asalusul berupa mithe dan legenda (Sutjipto Wirjosuparta, 1983:47\&51).

Dongeng bersifat universal dan banyak jumlahnya, namun menurut Anti

Arne dan Stith Thomson (dalam Danandjaya. 1986) dongeng dapat dibagi menjadi 4 jenis yaitu:

1. Dongeng binatang (animal tales) adalah dongeng yang ditokohi binatang peliharaan dan binatang liar, seperti binatang menyusui, binatang melata, ikan dan serangga. Binatang-binatang tersebut dalam ceritanya dapat berbicara dan berakal budi seperti manusia. Ada binatang cerdik, licik dan jenaka di satu pihak dan binatang pandir yang menjadi bulan-bulanan tipu muslihat di lain pihak. Di Indonesia banyak dongeng jenis ini, satu diantaranya adalah $\mathrm{Si}$ Kancil dan Si Siput, Kancil Menipu Kera dan lain-lainnya Rahimsyah (dalam Muh.Hanif, 2010:1).

2. Dongeng biasa (ordinary folkates) adalah jenis dongeng yang ditokohi manusia dan 
biasanya adalah kisah suka duka seseorang. Contohnya Cinderella, Ande-ande Lumut dan lain-lain.

3. Lelucon dan anekdot (jokes and anecdotes) adalah dongengdongeng yang dapat menimbulkan rasa menggelikan hati, sehingga menimbulkan tawa. Contohnya "Dongeng Modin Karok". (Sumenep Madura).

Dunia dimulai dengan cerita (Adam dan Hawa) dan berakhir dengan cerita (kiamat). Permulaan dan akhir kehidupan manusia diisi, diwarnai serta dijelaskan melalui cerita. Cerita benar-benar objek dan cara yang lekat dalam kehidupan manusia (Tadkiroatun Musfiroh, 2011:46). Heru Saputra (2007:72) berpendapat bahwa tradisi lisan adalah segala wacana yang diucapkan, baik yang lisan maupun yang beraksara, atau system wacana yang bukan beraksara.

Garraghan (dalam Dudung Abdurrahman, 2007:47) menyebutkan sejumlah tradisi lisan sebagai berikut:

a. Fable (fable) yaitu suatu cerita yang aktornya terdiri dari binatang-binatang buas, burungburung, makhluk hidup yang bukan manusia (makhluk gaib) atau personifikasi abstrak lainnya yang mengambil perwatakan manusia. Salah satu contohnya yaitu karya Hayy bin Yaqdan.

b. Dongeng (tale) yaitu suatu cerita yang berkaitan dengan waktu, tempat dan aktor yang tidak menentu. Sebagai contoh dongeng Si Kabayan dari tanah Pasundan.

c. Mitos (myth) yaitu suatu cerita atau sejenisnya yang bersumber seperti halnya sejarah, tetapi sarat dengan khayalan. Mitos selalu memuat tentang kehidupan manusia dan biasanya mengambil manusia super sebagai tokohnya. Contohnya Kisah para Wali Songo yang seringkali mengarah kepada bentuk mitologis oleh para pengagumnya.

d. Legenda (legend) yaitu suatu cerita yang dalam berbagai hal berisi kebenaran, termasuk di dalamnya elemen-elemen historis seringkali mengandung isi aktual.

e. Saga yaitu suatu cerita yang berpusat pada tokoh pahlawan. Saga biasanya merupakan cerita yang diambil dari fakta atau 
kebenaran dalam literatur dengan mengungkapkan tokohtokoh pahlawan dan nilai kepahlawanan.

Tadkiroatun Musfiroh (2011:47) cerita adalah sejarah yang perlu dipertanyakan kebenarannya sedangkan sejarah juga tentang cerita dan bercerita.

Cerita bisa sangat menggugah dan melibatkan berbagai emosi, mempengaruhi perilaku dan menentukan pengambilan keputusan seseorang manakala disampaikan secara efektif. Oleh sebab itu cerita bisa digunakan sebagai salah satu metode sosialisasi karakter kepada anak sejak dini dengan menggali kekuatannya. Kekuatan cerita dapat tergali melalui serangkaian kegiatan yang mengarahkan anak untuk melakukan perilaku berkarakter dan menanamkan konsep diri positif (Euis Sunarti, 2005:9). Peran cerita sangat sentral, sangat penting. Jika anak menyukai tokoh tertentu dalam cerita yang disampaikan, ada keinginan kuat dari mereka untuk menjadi tokoh tersebut (Jarot Wijanarko, 2005:59). adalah cerita yang dapat dipertanggungjawabkan

kebenarannya. Cerita tidak lahir dari kekosongan budaya, dan sejarah adalah pengisi kebudayaan itu. Hal ini menunjukkan bahwa berbicara tentang sejarah, berbicara

\section{Pengertian Sejarah}

Istilah "sejarah" berasal dari bahasa Arab, yakni dari kata "syajaratun" (dibaca syajarah), yang memiliki arti "pohon kayu". Pengertian "pohon kayu" di sini menunjukkan adanya suatu kejadian, perkembangan, atau pertumbuhan tentang suatu hal atau peristiwa dalam suatu kesinambungan (kontinuitas) (Tim Pengembang Ilmu Pendidikan UPI, 2007:341). Perkataan sejarah dalam bahasa Indonesia sama dengan history (Inggris), Geschichte (Jerman) atau geschiedenis (Belanda), (Moh.Ali, 2005:11).

R. Moh. Ali (2005:41) menyatakan bahwa jenis sejarah dapat dibedakan lagi jumlahnya apabila diperhatikan ruang hidup manusia, antara lain sebagai berikut: (a) Negara, nasional, misalnya sejarah Indonesia 
Philipina, India, Jerman, Inggris dan

Rusia; (b) lingkungan hidup kenegaraan, misalnya sejarah Asia Tenggara, Timur Tengah, Eropa dan Amerika Selatan; (c) lingkungan hidup kemasyarakatan, misalnya sejarah kota Jakarta, sejarah Kampung Duri dan Kelurahan Malimping; (keseluruhan) misalnya sejarah umum, sejarah Asia dan sejarah dunia.

Sejarah sebagai sebuah fenomena, memiliki bahan dasar cerita, suatu rangkaian fakta yang terjadi di masa lalu dan menjalin membentuk cerita. Dengan demikian sejarah merupakan cerita faktual (bukan fakta cerita) yang bernilai kebenaran tinggi (Tadkiroatun Musfiroh, 2011:46).

R. Moh. Ali dalam bukunya yang berjudul Pengantar Ilmu Sejarah Indonesia (1963:12) menyebutkan bahwa terdapat beberapa definisi. Definisi sejarah ada tiga hal yaitu; Pertama, yaitu kejadian-kejadian peristiwa seluruhnya yang berhubungan dengan yang nyata di dalam manusia sekitar kita. Kedua, yaitu cerita yang tersusun secara sistematis (serba rapi-teratur) dari kejadian-kejadian dan peristiwaperistiwa umum. Ketiga, yaitu ilmu (science) yang bertugas menyelidiki perkembangan-perkembangan negara-negara, peristiwa-peristiwa dan kejadian-kejadian lampau. Pada umumnya orang memakai istilah "sejarah" untuk menunjuk pada cerita sejarah, gambaran sejarah, pengetahuan sejarah yang kesemuanya itu mengartikan sejarah dalam arti "subjektif". Dikatakan "subjektif" karena tidak lain dalam sejarah memuat unsurunsur dari subjek (sejarawan ataupun penulis) tentang pengetahuan gambarannya yang merupakan rekonstruksi dari penulis atau sejarawan, di mana memuat sifat-sifatnya, gaya bahasanya, struktur pemikirannya, pandangan-pandangannya.

Kartodirdjo (dalam Tim Pengembang Ilmu Pendidikan UPI, 2007:341).

R. Moh. Ali (2005:12) berpendapat bahwa sejarah sebagai ilmu dan sejarah sebagai cerita adalah ciptaan manusia dan bukan sesuatu yang timbul atau terjadi di luar usaha manusia (seperti gunung meletus, air bah, badai topan). Manusia sebagai subjek atau pemegang peranan dalam membuat ilmu dan cerita. Dengan demikian ilmu sejarah dan cerita sejarah 
disebut sejarah serba subjek, artinya hasil perbuatan manusia. Sejarah bukan hanya semata-mata fakta belaka, tetapi sejarah adalah cerita.

"Perkataan sejarah dalam bahasa Indonesia adalah sama dengan "history" dari bahasa Inggris. Sejarah juga berasal dari kata benda Yunani yaitu "istoria". Menurut definisi umum, kata "history" berarti masa lampau manusia" (Louis Gottschalk, 1969:27).

Sejarah sebagai cerita merupakan hasil rekonstruksi sejarawan berdasarkan fakta-fakta dan penafsiran subjek/sejarawan terhadap peristiwa sejarah serba subjektif (Tim Pengembang Ilmu Pendidikan UPI, 2007: 341).

$\begin{array}{ccc}\text { Cerita } \quad \text { sejarah } & \text { tidak } \\ \text { membentang hal ihwal } & \\ \text { perseorangan, tidak melukis } & \\ & \end{array}$
kan peristiwa-peristiwa remeh sembarang orang, bahkan pula kejadian-kejadian yang merupakan rentetan peristiwa kehidupan kepribadian seseorang manusia sehari-hari saat ia bangun sampai waktu ia tidur (R. Moh. Ali, 2005:41).

Cerita sejarah berisi tentang suatu kejadian yang telah terjadi yang digambarkan seperti apa adanya. Cerita sejarah pada dasarnya adalah upaya menghadirkan peristiwa yang telah terjadi. Tetapi, tidak dalam arti membalikkan arah perputaran waktu sehingga peristiwa itu dapat dilihat kembali (Abdurrahman Hamid dan Muh. Saleh Madjid, 2011:55\&58).

Dari beberapa pendapat di atas dapat ditarik kesimpulan bahwa cerita sejarah adalah cerita faktual yang mengandung unsurunsur sejarah yang bernilai kebenaran tinggi di mana cerita sejarah juga mampu untuk merangsang minat baca peserta didik yang terkandung nilai-nilai moral serta petuah-petuah di dalamnya.

\section{B. Nilai-nilai Moral}

\section{Pengertian Nilai}

Abraham dkk (2008:105) menyebutkan bahwa nilai (value) adalah kualitas dari sesuatu yang bermanfaat bagi kehidupan manusia, baik lahir maupun batin. Nilai bersifat abstrak, hanya dapat dipahami, dipikirkan, dimengerti dan dihayati oleh manusia. Nilai berkaitan dengan harapan, cita-cita, keinginan dan segala sesuatu pertimbangan batiniah manusia. Nilai dapat 
bersifat subjektif bila diberikan oleh subjek dan bersifat obejktif bila melekat pada sesuatu yang terlepas sari penilaian manusia.

Kehidupan manusia dalam masyarakat, baik sebagai pribadi maupun sebagai kolektivitas, senantiasa berhubungan dangan nilai-nilai, norma dan moral. Nilai yaitu sesuatu yang berharga, yang berguna, yang indah, yang memperkaya batin, yang menyadarkan manusia akan harkat martabatnya. Nilai bersumber pada budi yang berfungsi mendorong, mengarahkan sikap dan perilaku manusia. Nilai sebagai suatu sistem merupakan salah satu wujud kebudayaan di samping sistem sosial dan karya (IKIP Malang, 1991:33).

Alo Liliweri (2002:108) menyebutkan bahwa nilai adalah sebuah kepercayaan yang didasarkan pada sebuah kode etik di dalam masyarakat. Nilai menunjukkan kepada kita tentang apa yang benar dan salah, baik dan buruk, ia juga menunjukkan tentang bagaimana seharusnya kita hidup sekarang dan akan datang, juga bagaimana pengalaman hidup di masa lalu.
Notonagoro (dalam IKIP Malang, 1991:34) membagi nilai dalam 3 kategori yaitu: 1. Nilai material, 2. Nilai vital dan 3. Nilai kerohanian. Sedangkan Nilai kerohanian sendiri dibagi menjadi 4 yaitu: 1. Nilai kebenaran, 2. Nilai keindahan, 3. Nilai moral dan 4. Nilai religi.

Nilai merupakan kualitas suatu hal yang menjadikan hal itu dapat disukai, diinginkan, berguna dan dihargai sehingga dapat menjadi semacam objek bagi kepentingan tertentu. Nilai juga merupakan sesuatu yang memberi makna dalam hidup, yang memberikan dalam hidup ini titik tolak, isi dan tujuan (Doni Koesoema, 2007:198-199).

Dari keempat pendapat di atas maka dapat ditarik kesimpulan bahwa nilai adalah sesuatu yang berharga, berguna dan indah yang terdapat di dalam norma masyarakat sehingga dapat mengarahkan sikap dan perilaku seseorang kea arah yang lebih baik.

\section{Pengertian Moral}

Secara etimologis, moral berasal dari bahasa latin mos (jamak: mores) yang mengandung arti adat kebiasaan. Moralitas mengandung beberapa pengertian 
antara lain: (a) adat istiadat, (b) sopan santun dan (c) perilaku (Nurul Zuriah, 2007:17).

Kehidupan manusia senantiasa berhubungan dengan nilai, norma dan moral. Moral pada dasarnya memiliki banyak arti. Dalam kamus psikologi disebutkan bahwa moral mengacu pada akhlak yang sesuai dengan peraturan sosial atau menyangkut hukum atau adat kebisaaan yang mengatur tingkah laku. Sementara dalam psikologi perkembangan disebutkan bahwa perilaku moral adalah perilaku yang sesuai dengan kode moral kelompok sosial. Moral sendiri berarti tata cara, kebiasaan dan adat (Dian Ibung Psi, 2009:3).

Frans Magnis Suseno (dalam Abraham dkk, 2008:106) menyebutkan bahwa moral selalu mengacu pada baik dan buruknya perbuatan manusia, sehingga bidang moral adalah bidang kehidupan manusia dilihat dari segi kebaikannya sebagai menusia.

Moral adalah ajaran tentang hal yang baik dan buruk yang menyangkut tingkah laku dan perbuatan manusia. Moral dalam perwujudannya dapat berupa aturan, prinsip-prinsip yang benar, yang baik, yang terpuji dan mulia (IKIP Malang, 1991:36).

Wiwit Wahyuning (2003:3) berpendapat bahwa moral berkenaan dengan norma-norma umum, mengenai apa yang baik atau benar dalam cara hidup seseorang.

Moral berhubungan dengan benar salah, baik buruk, keyakinan diri sendiri dan lingkungan sosial (Dian Ibung P.si, 2009:3).

Wiwit Wahyuning (2003:3) menyebutkan, bahwa ketika orang berbicara tentang nilai-nilai moral, pada umumnya akan terdengar sebagai sikap dan perbuatan seseorang terhadap orang lain. Pada anak-anak, nilai-nilai moral akan terlihat dan mampu tidaknya seorang anak membedakan antara yang baik dan yang buruk.

Pendidikan moral berusaha untuk mengembangkan pola perilaku seseorang sesuai dengan kehendak masyarakatnya. Kehendak ini berwujud moralitas atau kesusilaan yang berisi nilai-nilai dan kehidupan yang berada dalam masyarakat. Karena menyangkut dua aspek inilah, yaitu (a) nilai-nilai dan (b) kehidupan nyata, maka pendidikan moral lebih banyak membahas masalah dilema yang berguna untuk mengambil 
keputusan moral yang terbaik bagi diri dan masyarakatnya (Nurul Zuriah, 2007:19).

Dari beberapa pendapat di atas, dapat disimpulkan bahwa moral adalah suatu keyakinan tentang benar-salah, baik-buruk, sesuai dengan kesepakatan sosial yang mendasari tindakan atau pemikiran cara hidup seseorang.

\section{Metode Penelitian}

Penelitian ini merupakan penelitian kualitatif deskriptif yaitu penelitian yang menggambarkan suatu peristiwa atau kejadian yang terjadi pada saat sekarang. Penelitian ini menggunakan metode penelitian fenomenologi karena fenomena yang terjadi pada saat sekarang yaitu jarangnya para orangtua membacakan cerita untuk anak-anaknya. Mereka terlalu sibuk dengan pekerjaannya sendiri atau menurut sebagian besar orangtua, cerita sudah tergantikan dengan adanya media-media yang canggih dan lebih menarik yaitu CD, Play Station, Laptop dll. Littlejohn (dalam Pawito, 2007:54) berpendapat bahwa kata gejala (phenomenon yang bentuk jamaknya adalah phenomena) merupakan asal istilah fenomenologi dibentuk dan dapat diartikan sebagai suatu tampilan dari objek, kejadian, atau kondisi-kondisi menurut persepsi. Sebagai suatu gerakan dalam berfikir, fenomenologi dapat diartikan sebagai upaya studi tentang pengetahuan yang timbul karena rasa kesadaran ingin mengetahui. Objek pengetahuan berupa gejala atau kejadian-kejadian dipahami melalui pengalaman secara sadar. Fenomenologi menganggap pengalaman yang aktual sebagai data tentang realitas yang dipelajari.

Daymon dan Holloway (2008:162) menyatakan bahwa studi kasus adalah pengujian intensif, menggunakan berbagai sumber bukti (yang bisa jadi kualitatif, kuantitatif atau keduaduanya) terhadap satu entitas tunggal yang dibatasi oleh ruang dan waktu. Pada umumnya, studi kasus dihubungkan dengan sebuah lokasi. "Kasusnya" mungkin sebuah organisasi, sekumpulan orang seperti kelompok kerja atau kelompok sosial, komunitas, peristiwa, proses, isu maupun kampanye. Tujuan penelitian studi kasus adalah meningkatkan pengetahuan mengenai peristiwaperistiwa komunikasi kontemporer yang nyata dalam konteksnya.

1. Tempat dan Waktu Penelitian

Penelitian ini dilakukan di Desa Pandean Kecamatan Mejayan Kabupaten Madiun. Dipilihnya Desa ini karena lokasi ini mudah untuk 
dijangkau serta lokasi ini dipilih karena terdapat kesesuaian topik permasalahan dengan yang diteliti. Waktu yang diperlukan yaitu 3 bulan dari bulan Mei sampai Agustus 2012.

2. Sumber Data Penelitian

Sumber data yang digunakan yaitu sumber data primer dan sekunder. Sumber data primer yaitu sumber data sekunder yang didapat langsung dari peneliti contohnya angket, dokumentasi, dan observasi. Sedangkan sumber data sekunder contohnya data monografi Kelurahan Pandean, buku, jurnal.

\section{Responden}

Sampling atau sampel berarti contoh, yaitu sebagian dari seluruh individu yang menjadi objek penelitian. Tujuan penentuan sampel ialah untuk memperoleh keterangan mengenai objek penelitian dengan cara mengamati hanya sebagian dari populasi karena sulitnya untuk meneliti seluruh populasi, hal ini mengingat biaya dan waktu yang begitu banyak diperlukan jika harus meneliti seluruh populasi (Mardalis, 2007:55-56).

Penelitian ini menggunakan sampel Purposive Sample Sampling yaitu sampel yang bertujuan dan sampel yang dipilih dengan cermat hingga relevan dengan desain penelitian. Peneliti akan berusaha agar dalam sampel itu terdapat wakil-wakil dari segala lapisan populasi. Dengan demikian, diusahakan agar sampel itu memiliki ciri-ciri yang esensial dari populasi sehingga dapat dianggap cukup representatif (S. Nasution, 2004:98).

4. Pengambilan Data

Pengambilan data dalam penelitian ini yaitu menggunakan tehnik angket (questionnaire), wawancara (interview), observasi dan dokumentasi.

a. Angket.

$$
\text { Mardalis }
$$

berpendapat bahwa menggunakan kuisioner dapat dilakukan oleh banyak orang untuk mengantar dan menjemput kembali kuisioner tersebut setelah diisi oleh responden.

b. Observasi

Metode observasi adalah metode pengumpulan data yang digunakan untuk menghimpun data penelitian melalui pengamatan dan pengindraan (Burhan Bungin, 2007:115). 
Penelitian observasi yang

digunakan yaitu peneliti

mendatangi tempat observasi yang terdiri dari anak-anak yang bermain di halaman seorang penduduk dan di sekolah TK Pembina pada jam istirahat kemudian peneliti mengamati perilaku atau tingkah laku anakanak yang bermain tersebut dan diamati apakah anak-anak yang dibacakan cerita/dongeng oleh orangtuanya dapat menerapkan nilai-nilai moral dalam lingkungan bermainnya.

c. Dokumentasi

Teknik pengumpulan data dilakukan dengan dokumen. Dokumen merupakan catatan peristiwa yang sudah berlalu. Dokumen yang berbentuk tulisan misalnya; catatan harian, sejumlah kehidupan, ceritera, biografi, peraturan, kebijakan. Dokumen yang berbentuk gambar misalnya; foto, gambar hidup, sketsa dll. Dokumen yang berbentuk karya misalnya; karya seni, yang dapat berupa gambar, patung, film, arca, lukisan, artefak (Sugiyono, 2007: 240).

Data-data yang dikumpulkan dengan teknik dokumentasi cenderung merupakan data sekunder antara lain data monografi Kelurahan Pandean. Sedangkan data-data yang dikumpulkan dengan tehnik angket (kuisioner), observasi merupakan data primer karena didapat langsung dari pihak pertama.

5. Analisa Data

Analisis data yang digunakan peneliti yaitu sebagai berikut:

a. Semua jawaban yang telah diterima kembali, segera dicek sudah lengkap atau belum jawaban-jawaban tersebut, kalau belum diperlukan dikirim lagipada orang yang bersangkutan atau tidak, untuk melengkapi data-datanya.

b. Setelah selesai, kemudian mentabulasikan hasil-hasil jawaban ke dalam daftar tabulasi, dan untuk sementara bagi jawaban yang kurang lengkap, dipisahkan terlebih dahulu.

c. Mempertimbangkan jawabanjawaban yang kurang lengkap ataupun yang simpang siur, apakah dengan kurang lengkapnya jawaban atau simpang siurnya jawaban itu telah dianggap valid (sahih) 
ataukah perlu diulang kembali

(recheeking dan probing).

d. Bila

dipandang dicukupkan dengan kualitatif (pernyataan-pernyataan atau statement saja).

permasalahannya cukup simpel,

Miles dan Huberman menawarkan tehnik analisis yang disebut dengan interactive model. Teknik analisis pada dasarnya terdiri dari tiga komponen

yaitu: reduksi data (data reduction), penyajian data (data display), penarikan serta pengujian kesimpulan (drawing and verifying conclusions).

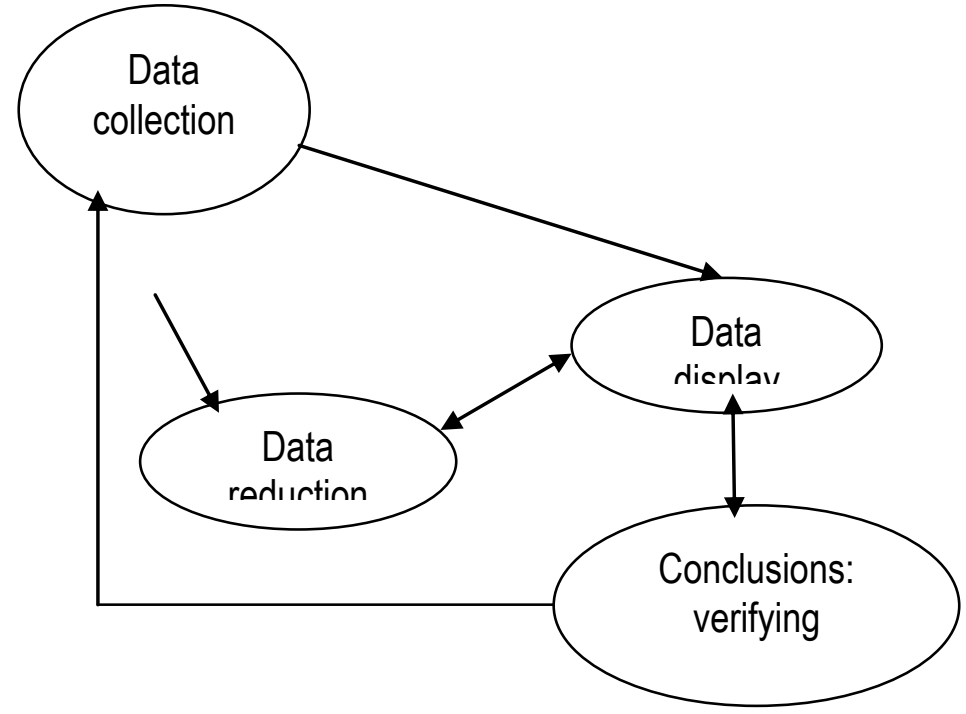

Bagan 1: Komponen dalam analisis data (interactive model)

\section{Hasil Penelitian}

\section{A. Bentuk-bentuk Cerita Sejarah di Kelurahan Pandean}

Cerita sejarah yang diceritakan ibu-ibu di Pandean kepada anaknya sangat beragam jenisnya sehingga peneliti harus memaparkan data agar lebih jelas. Bentuk cerita yang diceritakan ibu-ibu Pandean kepada anaknya yaitu antara lain berupa cerita rakyat, dongeng, cerita agama. Untuk lebih jelasnya dapat dilihat pada tabel di bawah ini:

Tabel 1 Cerita yang Dibacakan oleh Responden

\begin{tabular}{|c|l|l|}
\hline No. & \multicolumn{1}{|c|}{ Nama Responden } & \multicolumn{1}{c|}{ Cerita yang dibacakan } \\
\hline 1. & Ibu Elly & Si Kancil yang cerdik \\
\hline 2. & Ibu Rita & Cerita kartun \\
\hline 3. & Ibu Winarti & Si Kancil yang Cerdik \\
\hline 4. & Ibu Sinta & Gorilla yang sombong \\
\hline
\end{tabular}




\begin{tabular}{|c|l|l|}
\hline 5. & Ibu Tina & $\begin{array}{l}\text { Harimau kecil tidak mau mandi, pergi ke Dr. } \\
\text { gigi, Anissa punya adik, Tidur siang. }\end{array}$ \\
\hline 6. & Ibu Yanti & Malin Kundang \\
\hline 7. & Ibu Titin & Cerita tentang pahlawan \\
\hline 8. & Ibu Demes & Si Kancil yang cerdik \\
\hline 9. & Ibu Vivi & Malin Kundang \\
\hline 10. & Ibu Tarmi & Cerita agama \\
\hline 11. & Ibu Siti & Malin Kundang \\
\hline 12. & Ibu Endar & Malin Kundang \\
\hline 13. & Ibu Shin & Cerita tentang sepakbola \\
\hline 14. & Ibu Yus & Cerita tentang hantu \\
\hline 15. & Ibu Nur & Cerita kisah Nabi \\
\hline 16. & Ibu Minah & Malin Kundang \\
\hline 17. & Ibu Budi & Cerita tentang kisah-kisah Nabi, cerita hewan \\
\hline 18. & Ibu Rachma & Malin Kundang \\
\hline 19. & Ibu Lina & Cerita hantu \\
\hline 20. & Ibu Sri & Malin Kundang \\
\hline 21. & Ibu Ningsih & Cerita Agama \\
\hline 22. & Ibu Amel & Malin Kundang \\
\hline 23. & Ibu Nana & Cerita Kelinci lomba lari dengan Siput \\
\hline 24. & Ibu Yuli & Malin Kundang \\
\hline 25. & Ibu Milah & Cerita mengenai sepakbola \\
\hline 26. & Ibu Retno & Malin Kundang \\
\hline & &
\end{tabular}

Dari hasil penelitian ditemukan

bahwa dari 36 responden ternyata terdapat 26 responden yang membacakan cerita kepada anakanknya dengan tujuan ibu-ibu membacakan cerita untuk anak mereka karena berbagai alasan yang disebutkan. Berikut tabel yang disajikan agar lebih jelas:

Tabel 2 Tujuan Bercerita oleh Responden

\begin{tabular}{|c|c|c|c|c|}
\hline No & $\begin{array}{c}\text { Nama } \\
\text { Responden }\end{array}$ & $\begin{array}{c}\text { Cerita yang } \\
\text { disampaikan, (jika } \\
\text { ya, apa?) }\end{array}$ & $\begin{array}{c}\text { Adakah Orang lain } \\
\text { yang bercerita } \\
\text { selain Orangtua? }\end{array}$ & Tujuan \\
\hline 1. & Ibu Elly & Si Kancil yang cerdik & Tidak ada & $\begin{array}{l}\text { Agar anak bisa } \\
\text { membedakan } \\
\text { yang baik dan } \\
\text { buruk }\end{array}$ \\
\hline 2. & Ibu Rita & Cerita kartun & Tidak ada & $\begin{array}{l}\text { Agar anak } \\
\text { senang }\end{array}$ \\
\hline 3. & Ibu Winarti & Si Kancil yang Cerdik & Ada, nenek & $\begin{array}{l}\text { Agar } \\
\text { menambah } \\
\text { pengetahuan } \\
\text { tentang } \\
\text { dongeng }\end{array}$ \\
\hline 4. & Ibu Sinta & Gorilla & Tidak ada & Agar anak \\
\hline
\end{tabular}




\begin{tabular}{|c|c|c|c|c|}
\hline No & $\begin{array}{c}\text { Nama } \\
\text { Responden }\end{array}$ & $\begin{array}{c}\text { Cerita yang } \\
\text { disampaikan, (jika } \\
\text { ya, apa?) }\end{array}$ & $\begin{array}{c}\text { Adakah Orang lain } \\
\text { yang bercerita } \\
\text { selain Orangtua? }\end{array}$ & Tujuan \\
\hline & & sombong & & $\begin{array}{l}\text { berbuat } \\
\text { kebaikan }\end{array}$ \\
\hline 5. & Ibu Tina & $\begin{array}{l}\text { Harimau kecil tidak } \\
\text { mau mandi, pergi ke } \\
\text { Dr. gigi, Anissa punya } \\
\text { adik, Tidur siang. }\end{array}$ & Tidak ada & $\begin{array}{l}\text { Terdorong } \\
\text { minat anak } \\
\text { untuk } \\
\text { membaca }\end{array}$ \\
\hline 6. & Ibu Yanti & Malin Kundang & Ada, kakek & $\begin{array}{l}\text { Agar anak } \\
\text { hormat pada } \\
\text { orang tua } \\
\end{array}$ \\
\hline 7. & Ibu Titin & $\begin{array}{l}\text { Cerita tentang } \\
\text { pahlawan }\end{array}$ & Tidak ada & $\begin{array}{l}\text { Agar } \\
\text { menghormati } \\
\text { para pahlawan } \\
\text { yang gugur }\end{array}$ \\
\hline 8. & Ibu Demes & Si Kancil yang cerdik & Tidak ada & $\begin{array}{l}\text { Agar anak tidak } \\
\text { meniru } \\
\text { perbuatan } \\
\text { mencuri }\end{array}$ \\
\hline 9. & Ibu Vivi & Malin Kundang & Ada, nenek & $\begin{array}{l}\text { Agar tidak } \\
\text { berani dengan } \\
\text { orangtua } \\
\end{array}$ \\
\hline 10. & Ibu Tarmi & Malin Kundang & Ada, kakek & $\begin{array}{l}\text { Agar sayang } \\
\text { kepada } \\
\text { orangtua }\end{array}$ \\
\hline 11. & Ibu Siti & Malin Kundang & Ada, ayahnya & $\begin{array}{l}\text { Agar hormat } \\
\text { kepada } \\
\text { orangtua }\end{array}$ \\
\hline 12. & Ibu Endar & $\begin{array}{l}\text { Cerita tentang } \\
\text { sepakbola }\end{array}$ & Ada, nenek & $\begin{array}{l}\text { Agar } \\
\text { mengetahui } \\
\text { tentang } \\
\text { olehraga } \\
\text { sepakbola } \\
\end{array}$ \\
\hline 13. & Ibu Shin & Cerita tentang hantu & Tidak ada & $\begin{array}{l}\text { Agar anak } \\
\text { cepat tidur }\end{array}$ \\
\hline 14. & Ibu Yus & Cerita kisah Nabi & Ada, nenek & $\begin{array}{l}\text { Agar } \\
\text { pengetahuan } \\
\text { agama lebih } \\
\text { luas }\end{array}$ \\
\hline 15. & Ibu Nur & Malin Kundang & Tidak ada & $\begin{array}{l}\text { Agar hormat } \\
\text { orangtua }\end{array}$ \\
\hline 16. & Ibu Minah & $\begin{array}{l}\text { Cerita tentang kisah- } \\
\text { kisah Nabi, cerita } \\
\text { hewan }\end{array}$ & Tidak ada & $\begin{array}{l}\text { Agar } \\
\text { mengetahui } \\
\text { kisah-kisah } \\
\text { nabi }\end{array}$ \\
\hline 17. & Ibu Budi & Malin Kundang & Ada, nenek & $\begin{array}{l}\text { Agar anak tidak } \\
\text { berani dengan } \\
\text { orangtua }\end{array}$ \\
\hline
\end{tabular}




\begin{tabular}{|l|l|l|l|l|}
\hline No & \multicolumn{1}{|c|}{$\begin{array}{c}\text { Nama } \\
\text { Responden }\end{array}$} & $\begin{array}{c}\text { Cerita yang } \\
\text { disampaikan, (jika } \\
\text { ya, apa?) }\end{array}$ & $\begin{array}{c}\text { Adakah Orang lain } \\
\text { yang bercerita } \\
\text { selain Orangtua? }\end{array}$ & Tujuan \\
\hline 18. & Ibu Rachma & Cerita hantu & Tidak ada & $\begin{array}{l}\text { Agar anak } \\
\text { cepat tidur }\end{array}$ \\
\hline 19. & Ibu Lina & Malin Kundang & Tidak ada & $\begin{array}{l}\text { Agar anak } \\
\text { sayang } \\
\text { orangtua }\end{array}$ \\
\hline 20. & Ibu Sri & Malin Kundang & Tidak ada & $\begin{array}{l}\text { Agar hormat } \\
\text { orangtua }\end{array}$ \\
\hline 21. & Ibu Ningsih & Cerita Agama & Tidak ada & $\begin{array}{l}\text { Agar anak tidak } \\
\text { berani } \\
\text { orangtua }\end{array}$ \\
\hline 22. & Ibu Amel & Malin Kundang & Ada, kakek & $\begin{array}{l}\text { Agar anak } \\
\text { sayang } \\
\text { orangtua }\end{array}$ \\
\hline 23. & Ibu Nana & $\begin{array}{l}\text { Cerita Kelinci lomba } \\
\text { lari dengan Siput }\end{array}$ & Ada, nenek & $\begin{array}{l}\text { Agar } \\
\text { mengambil } \\
\text { nilai kebaikan } \\
\text { dari Siput }\end{array}$ \\
\hline 24. & Ibu Yuli & Malin Kundang & Ada, ayahnya & $\begin{array}{l}\text { Agar hormat } \\
\text { orangtua }\end{array}$ \\
\hline 25. & Ibu Milah & $\begin{array}{l}\text { Cerita mengenai } \\
\text { sepakbola }\end{array}$ & Ada, nenek & $\begin{array}{l}\text { Agar tidak } \\
\text { berani kepada } \\
\text { orangtua }\end{array}$ \\
\hline 26. & Ibu Retno & Malin Kundang & Tidak ada & $\begin{array}{l}\text { Agar sayang } \\
\text { orangtua }\end{array}$ \\
\hline
\end{tabular}

Dari paparan di atas, dapat diketahui bahwa para ibu-ibu di Pandean sebagian besar membacakan cerita rakyat Malin Kundang kepada

\section{B. Pembelajaran Cerita Sejarah}

\section{kepada Anak-anak di Pandean}

Jenis cerita yang dibacakan ibuibu untuk membacakan cerita untuk anaknya yaitu jenis cerita rakyat, akan tetapi di Kelurahan Pandean cerita sejarah dan cerita dongeng mempunyai peran yang penting karena untuk mengenalkan kepada anak-anak tentang nilai-nilai moral yang diterapkan. Sasaran penelitian disini yaitu anak- anak-anaknya dengan tujuan agar anak tidak berani kepada orangtua, hormat kepada orangtua, lebih sayang kepada orangtua.

anak yang berumur 1-6 tahun. Angket disebarkan kepada KK yang mempunyai anak umur 1-6 tahun dengan dasar keragaman profesi atau yang berarti ibu-ibu yang bekerja sebagai wanita karier di perusahaan atau PNS, maka cerita sejarah merupakan cerita pengantar tidur anak karena disesuaikan dengan waktu. Penelitian ini terdiri dari beberapa profesi 
sehingga didapatkan hasil keragaman penelitian.

\section{Peran Sekolah dalam}

\section{Pembelajaran Cerita Sejarah}

Sekolah juga merupakan fasilitator dalam pembelajaran cerita sejarah, di sini sekolah berperan untuk pembelajaran cerita sejarah. Di SD Pandean 01 dalam bahasan muatan lokal terdapat mata pelajaran Bahasa Daerah, Bahasa Jawa. Di sini disisipkan pembelajaran tentang sejarah daerah atau sejarah lokal yaitu Sejarah Pandean. Proses ini bertujuan untuk mengenalkan peserta didik agar tidak buta akan sejarah lokal dalam pengetahuan mereka. Selain itu pula, di SD Pandean terdapat pendidikan budi pekerti yangmenanamkan nilai-nilai sikap, tata perilaku, sopan santun, norma dan akhlak (wawancara Budi Hariyati, tanggal 12 Agustus 2012). Pendidikan moral juga diterapkan melalui PAUD, TK Pembina, SD Pandean 1 di Kelurahan Pandean Sekolah dapat menanamkan moral peserta didik melalui cerita Pandean. Cerita sejarah Pandean ini harus ditanamkan kepada peserta didik agar dapat menjadi tradisi lisan bagi generasi selanjutnya.

2. Peran Lembaga Pendidikan dalam Penanaman Nilai-nilai Cerita Sejarah
Lembaga pendidikan seperti sekolah TK Pembina, balai Kelurahan Pandean, pra-sekolah (PAUD), SD Pandean 01 dapat berperan dalam penanaman nilai-nilai cerita sejarah. Misalnya di sekolah anak dapat mengetahui cerita tentang Kelurahan Pandean melalui tenaga pendidik mereka. Akan tetapi, di Kelurahan Pandean hanya sedikit tenaga pendidik yang menceritakan sejarah Pandean. Maka dari itu, solusi yang peneliti sarankan yaitu diperlukan pengetahuan tambahan tenaga pendidik di pendidikan PAUD, TK Pembina, SD Pandean 01 dalam memasukkan nilai-nilai moral kepada anak.

Selain itu, di Balai Kelurahan juga berperan dalam penanaman nilai-nilai cerita sejarah yaitu terdapat Posyandu yang diadakan setiap tanggal 19 dalam 1 bulan. Setelah anak-anak diimunisasi akan ada penyuluhan tentang sejarah Pandean kepada ibu-ibu. Terdapat perangkat desa yang memberi bahasan tentang cerita sejarah Pandean sehingga ibu-ibu perlu mengetahui asal usul tempat mereka bermukim.

Lembaga masyarakat juga turut berperan dalam pemberian nilai-nilai sejarah lokal di Pandean. 
Di Pandean, 5 hari setelah Idul Fitri biasanya diadakan bersih desa yaitu upacara tolak bala yang intinya upacara untuk mendoakan penunggu Pandean agar masyarakat Pandean mendapat keselamatan. Upacara ini rutin dilakukan oleh masyarakat Pandean selama 1 tahun sekali. Di dalam upacara

ini juga dimaksudkan untuk menanamkan pemahaman tentang

\section{Pembahasan}

\section{A. Nilai-nilai yang terkandung}

\section{dalam cerita rakyat Malin}

\section{Kundang bagi anak-anak}

Nilai-nilai yang dapat diambil

dari cerita Malin Kundang sangat beragam maknanya untuk anak-anak PAUD, TK, dan SD karena di dalamnya terdapat pesan moral yang sarat akan pendidikan dan menggambarkan maksud dan tujuan dari cerita itu sendiri. Dari hasil survey peneliti dapat diketahui bahwa karakter dari masingmasing tokoh yaitu:

a. Ibu Malin Kundang memiliki karakter penyayang, pengasih, pemaaf, bertanggungjawab.

b. Malin Kundang memiliki karakter sayang terhadap orangtua, patuh terhadap orangtua (awal cerita), pemberani, sombong, berani kepada sejarah Pandean dan menanamkan nilai-nilai kearifan lokal bagi masyarakat Pandean. Upacara bersih desa ini biasanya menampilkan hiburan Reog Ponorogo yang menarik. Hal ini juga mengenalkan warisan budaya yang harus dilestarikan oleh para generasi selanjutnya agar tidak hilang ditelan masa.

orangtua (akhir cerita), pekerja keras.

Paparan di atas menunjukkan bahwa terdapat nilai-nilai positif yang membantu anak usia dini untuk memetik pelajaran dari setiap perbuatan yang ada di cerita Malin Kundang. Cerita Malin Kundang juga cerita yang sangat mendidik untuk anak usia dini karena di sini mereka mengetahui bagaimana kasih sayang seorang ibu yang melahirkan mereka sangat berperan penting dalam kehidupan mereka dan betapa ibu sangat mengorbankan nyawa untuk melahirkan seorang bayi ke dunia ini. Sehingga apabila suatu saat mereka menjadi berani kepada ibu maka akan "kualat" di suatu hari nanti.

Wujud nilai-nilai moral yang ada dalam cerita Malin Kundang meliputi hubungan manusia dengan Tuhan 
berupa sikap berdoa kepada Tuhan dan bersyukur kepada Tuhan, hubungan manusia dengan manusia lain berupa berbakti kepada orang tua, tolong menolong, kasih sayang ibu terhadap anaknya, meminta maaf, berterima kasih, hubungan manusia dengan dirinya sendiri berupa sadar akan perbuatan salah, rajin berkerja. Wujud nilai moral yang paling sering muncul dalam cerita rakyat Malin Kundang adalah hubungan manusia dengan Tuhan. Bentuk penyampaian nilai-nilai moral yang digunakan melalui penyampaian secara langsung dan tidak langsung. Dalam cerita rakyat Malin Kundang bentuk penyampaian nilai moral yaitu secara langsung, yang paling dominan muncul adalah ketika Ibu Malin Kundang berdoa kepada Tuhan agar anaknya diberi kutukan karena Malin Kundang telah durhaka dan tidak mau mengakui dirinya sebagai Ibunya.

Malin Kundang adalah sebuah legenda yang diceritakan secara turunmenurun dan sudah menjadi cerita rakyat Indonesia. Cerita rakyat Malin Kundang ini adalah sebuah fakta di daerah Padang, Sumatera Barat. Berikut adalah beberapa fakta mengenai Malin Kundang yang sudah di kenal oleh masyarakat luas:

1. Malin Kundang adalah cerita rakyat mengenai anak durhaka yang tidak mengakui ibunya sehingga ibunya menjadi marah dan mengutuk Malin Kundang menjadi batu. Cerita ini berasal dari daerah Sumatera Barat.

2. Banyak cerita serupa yang beredar di Asia Tenggara. Di Malaysia cerita Malin

Kundang lebih dikenal dengan nama Si Tenggang. Kisah ini di tulis oleh Walter William Skeat sebagai salah satu cerita rakyat berjudul Sajobang Charitra Megat dalam buku Malay Magic (1900) dan dicetak oleh The Macmillan Company, New York (http://www.studentmagz.com/favi con diakses tgl 13 Juli 2012).

3. Adanya batu yang menyerupai manusia yang sedang bersujud di Ranah Minang yang di pecayai sebagai wujud membatunya si Malin Kundang. Batu ini terletak di Pantai Air Manis yang lokasinya kurang lebih 30 menit dari kota Padang, arah selatan.

4. Belum pernah ada yang bisa membuktikan jika di dalam batu tersebut benar adalah Malin Kundang. Jika dilihat dari batu yang berada di Pantai Air Manis maka yang terlihat adalah sebuah batu pahatan yang di pahat menyerupai manusia yang sedang membungkuk. Selain itu di situs tersebut juga terdapat rongsokan-rongsokan 
kapal berserta dengan pecahanpecahannya yang berantakan.

5. Cerita rakyat Malin Kundang kaya akan pesan-pesan moral. Pesan bahwa perkataan Ibu yang berbakti dan rela berkorban demi kebahagiaan anaknya adalah benar adanya. Hal ini berkaitan erat dengan surga berada di telapak kaki ibu. Cerita rakyat ini menggambarkan betapa hebatnya seorang ibu dan bahwa dengan menghormati ibu yang telah melahirkan dan menjaga kita maka niscaya Allah juga akan mendengarkan doa ibu tentang kita.

6. Malin Kundang adalah gambaran manusia pada umumnya. Banyak sekali

orang yang lupa akan perjuangan orang di sekitarnya untuk membantu Malin sampai sukses. Malin malu mengakui darimana sebenarnya ia berasal. Hal ini sesuai dengan peribahasa "Kacang yang lupa akan kulitnya". Sifat Malin Kundang yang demikian yang menjadi perenungan bagi kita semua agar kita selalu bisa rendah hati dan tidak sombong seperti Malin Kundang.

Amanat atau pesan yang terkandung dalam ringkasan cerita rakyat yang berjudul Malin Kundang adalah :

a. Janganlah durhaka terhadap orang tua apalagi terhadap ibu kita. Durhaka terhadap orang tua apalagi terhadap seorang ibu merupakan perilaku yang tercela dan sangat dilarang oleh agama. Ingatlah bahwa Surga berada di bawah telapak kaki ibu. Oleh karena itu, berprilaku baik dan lemah lembut terhadap ibu kita.

b. Janganlah berlaku dan berkata kasar terhadap ibu kita yang telah melahirkan kita.

c. Janganlah meniru sikap dan watak Malin Kundang yang menghardik ibunya, serta berkata-kata yang menyakitkan hati ibunya. Ingatlah bahwa seorang ibu telah mengandung kita selama kurang lebih 9 bulan lamanya dalam kandungan. Seorang ibu telah berjuang mempertaruhkan nyawanya demi untuk melahirkan anaknya ke muka bumi ini.

d. Jangan pernah untuk melupakan ibu yang telah mengandung, melahirkan dan membesarkan kita. Jika kita telah menjadi seorang yang sukses di kemudian hari, janganlah pernah melupakan ibu yang telah mengandung, melahirkan dan membesarkan kita. 
Pada cerita ini, Malin Kundang setelah menjadi saudagar yang kaya dan memiliki seorang istri yang cantik jelita, ia lupa akan ibunya kandungnya sendiri. Ia berlaku kasar terhadap ibunya, dan menorehkan luka yang membuat pedih hati ibunya. Sehingga di akhir

\section{B. Budaya Bercerita kepada anak-} anak usia dini di Kelurahan

\section{Pandean dalam Era Teknologi}

Dalam era teknologi sekarang ini banyak media yang menarik untuk menyajikan cerita-cerita yang mendidik bagi anak-anak sekarang khususnya anak-anak usia dini. Cerita atau dongeng telah mengalami degradasi yang cukup tinggi, para orangtua tidak sadar bahwa dengan bercerita akan merangsang atau mengajarkan anak untuk membaca dan menggali lebih mendalam tentang buku. Sekarang di jaman yang serba canggih ini, anak mulai disuguhkan dengan film dan permainan anak yang makin menjamur sehingga mereka sekarang lebih mengenal tokoh seperti Spongebob, Shaun The Sheep, Bernard, Angry Bird daripada mengenal tokoh Sangkuriang, Malin Kundang, Arjuna, Semar dan tokoh dalam dongeng atau cerita sejarah.

Di Kelurahan Pandean, budaya bercerita atau mendongeng sangat cerita, karena kebesaran yang ditunjukkan oleh Tuhan berupa badai disertai petir, Malin Kundang si anak durhaka tenggelam bersama kapalnya, dan konon karena kutukan ibunya ia berubah menjadi batu.

ditanamkan oleh para orangtua. Menurut mereka, seni bercerita sangat penting karena mengajarkan kepada anak dalam membangun karakter. Jaman modern banyak mempengaruhi mindset para orangtua dengan memberikan CD dalam bentuk cerita kepada anak. Penggunaan CD cerita akan lebih efisien dan budaya bercerita secara langsung dari orangtua akan menghilang.

Di Kelurahan Pandean, budaya bercerita tentang sejarah lokal yaitu Sejarah Pandean juga diterapkan di PAUD, TK, dan SD melalui mata pelajaran muatan lokal. Mata pelajaran muatan lokal disini yaitu Bahasa Daerah. Guru mengajar Bahasa Daerah dengan cara bercerita, yaitu tentang Pandawa Lima, Gatotkaca, Semar tergantung dari pembahasan materi yang diajar. "Saya kalau mengajar itu ya dengan cerita biar siswa lebih tertarik dan mendengar apa yang saya bicarakan. Dalam pembelajaran Bahasa Daerah, saya juga sering menyisipkan 
cerita tentang sejarah Desa Pandean karena agar supaya siswa mengetahui dan memahami tentang Sejarah Desa Pandean, siapa saja pendirinya, bagaimana asal mulanya disebut Pandean, dan dimana letak makamnya. Sehingga siswa bisa mencari tahu tentang hal tersebut. Di dekat SD Pandean juga terdapat makam para pendiri Pandean yaitu Kyai Demang, Nyai Endah, Kyai Wadat, Nyai Wadat, dan Kyai Trobanyu" (wawancara dengan Moch. Rodji, S.Pd tanggal 02 Agustus 2012).

Penanaman nilai-nilai luhur dapat ditanamkan kepada anak didik karena dengan mengetahui tentang Sejarah Pandean, mereka juga tidak buta akan sejarah lokal. Mereka juga bisa melihat makam kelima pendiri Pandean tersebut di dekat SDN 01 Pandean. "Di dalam pembelajaran juga diterapkan pendidikan budi pekerti yang masuk menjadi pendidikan karakter anak, yaitu anak diajarkan cara menghormati orang yang lebih tua, menghormati para leluhur yang ada di Pandean, dan juga menanamkan budi pekerti yang baik agar siswa menjadi lebih baik dan bermoral, tetapi semua itu tergantung dari penanaman moral dan norma yang ada di keluarga itu sendiri, apakah diajarkan oleh orangtua mereka atau tidak. Disini kita sebagai tenaga pendidik hanya membantu untuk mewujudkan manusia yang berkarakter dan memiliki nilai budi pekerti yang luhur (wawancara dengan Moch. Rodji, S.Pd tanggal 02 Agustus 2012).

Cerita rakyat, dongeng, fabel, legenda merupakan cerita yang biasanya diceritakan secara turun temurun. Menyampaikan cerita secara lisan sudah dikenal sejak dahulu, baru setelah orang mengenal media cetak dongeng-dongeng ini dituliskan. Selain sarat dengan pesan-pesan, budaya bercerita biasanya disampaikan secara menarik agar pendengar (anak-anak) dapat terlibat langsung dengan cerita tersebut bahkan mereka menjadi tokoh yang mereka inginkan dalam cerita. Cerita bukan sekedar untuk mengisi waktu atau sebagai hiburan melainkan untuk menyampaikan suatu ajaran atau pesan.

Di Kelurahan Pandean, sejarah lokal disampaikan secara lisan agar dapat diteruskan oleh para generasi selanjutnya untuk dapat tetap melestarikan budaya asal-usul sebuah tempat. Tetapi, selain budaya bercerita masih dilakukan oleh ibu-ibu di Pandean ternyata terdapat beberapa kendala dalam membudayakan cerita tersebut yaitu:

1. Anak-anak kadangkala malas bila orangtua akan membacakan cerita 
untuk mereka biasanya mereka ingin bermain-main dulu dengan ibu atau ayahnya

sebelum dibacakan cerita.

2. Anak jarang untuk meminta dibacakan dongeng oleh orangtua mereka.

3. Orangtua kadangkala sibuk dengan pekerjaan rumah atau sibuk dengan pekerjaan di kantor sehingga jarang membacakan cerita untuk anak mereka.

4. Anak jarang mau mendengarkan dongeng dari orangtua karena mereka lebih suka melihat dongeng atau cerita dari televise.

5. Orangtua malas membacakan cerita kepada anak.

6. Orangtua kadang kehabisan ide/bahan untuk bercerita kepada anak.

Para orangtua di Pandean membacakan cerita untuk anaknya

C. Faktor-faktor Pendukung dalam Budaya Bercerita

Faktor pendukung dalam

budaya bercerita di Pandean yaitu:

1. Dari orangtua:

a) Orangtua mempunyai media yaitu buku cerita, boneka jari, bahan-bahan di tidak hanya di waktu akan tidur saja, tetapi di saat waktu senggang mereka membacakan cerita-cerita untuk anaknya. Cara penyampaian cerita kepada anak yaitu dengan menggunan metode bercerita agar anak tertarik dengan cerita yang dibacakan, misalnya; menirukan suara binatang, menirukan suara tokoh-tokoh atau karakter tokoh yang ada dalam cerita, intonasi yang sesuai dengan alur cerita. Buku cerita juga bisa digunakan sebagai pedoman untuk anak agar lebih mendengarkan orangtua dalam bercerita karena di dalam buku cerita sering terdapat gambar-gambar untuk mendeskripsikan isi cerita tersebut. Mayoritas yang menceritakan cerita untuk anakanaknya yaitu ibu karena ibu-ibu di Pandean mempunyai cukup waktu untuk membacakan cerita bagi anakanak mereka.

sekitar yang bisa dijadikan media dalam membacakan cerita kepada anak.

b) Orangtua mempunyai metode bercerita untuk anak yaitu dengan memfokuskan perhatian kepada anak melalui kontak mata, pintar dalam mengolah vokal, mimik muka (ekspresi) yang menunjukkan isi dari cerita. 
2. Dari anak:

a) Anak dapat mengerti dan memahami cerita melalui ajaran orangtua, sehingga anak dapat mengerti apa maksud dari cerita tersebut.

b) Anak akan terdorong untuk membaca buku sendiri jika orangtua yang mengawalinya membacakan cerita.

3. Dari masyarakat:

a) Masyarakat Pandean melakukan sosialisasi yang isinya menceritakan tentang sejarah Pandean kepada ibu-ibu yang ada di Posyandu agar lebih memahami tentang sejarah daerahnya sendiri.

b) Setiap menjelang lebaran Idul Fitri 2 hari sebelumnya, masyarakat Pandean melakukan upacara bersih desa di dekat SD

\section{Penutup}

\section{A. Simpulan}

Dari analisa data tersebut di atas dapat disimpulkan bahwa nilai-nilai moral yang dapat diambil dari cerita Malin Kundang yaitu tidak boleh durhaka kepada orangtua, harus menghormati orangtua, pemberani, pantang menyerah, pekerja keras. Kemudian pesan moral yang dapat
Pandean 01 yaitu makam penunggu atau leluhur Pandean untuk memberikan sesaji atau cok bakal kepada leluhur dengan tujuan agar masyarakat Pandean terbebas dari malapetaka. Kegiatan ini rutin dilakukan setiap menjelang Idul Fitri.

4. Dari lembaga pendidikan:

Di sekolah SD Pandean 01 disisipkan mata pelajaran muatan lokal Bahasa Daerah. Dalam pembelajarannya, guru mengajar Bahasa Daerah dengan bercerita yang mengandung unsur sejarah yaitu cerita tentang Gatotkaca, Pandawa Lima dan lain sebagainya dan guru juga menceritakan tentang Sejarah Pandean dengan tujuan agar siswa memahami dan mengetahui tentang sejarah berdirinya Pandean.

diambil oleh anak usia dini dalam cerita Malin Kundang ini adalah sebagai anak, tidak boleh durhaka kepada orangtua terutama kepada ibu karena apabila berani kepada ibu akan mendapat ganjaran dari Tuhan yaitu doa ibu bagi anaknya yang durhaka akan sangat terkabul.

Penelitian menunjukkan bahwa dari 36 responden hanya 26 responden yang membacakan cerita untuk anak- 
anak mereka. Jadi, hanya 35\% para orangtua di Pandean yang membacakan cerita kepada anak-anaknya. Cerita yang dibacakan beragam baik itu cerita sejarah, cerita dongeng, legenda atau cerita persuasif yang mendorong anak untuk mau melakukan kebiasaan yang baik. Contohnya: cerita tentang Anissa pergi ke Dr. gigi, ini menunjukkan cerita yang mengandung unsur persuasif yaitu membujuk anak agar mau pergi ke Dr. gigi dan tidak takut akan keberadaan Dr. gigi. Selain itu, orangtua di Pandean ada juga yang membacakan kisah-kisah Nabi agar anaknya mengerti tentang keberadaan agamanya yang dianutnya. Respon anak-anak setelah dibacakan cerita sangat beragam, ada yang senang, takut, gembira, dan ada yang ingin cerita itu diulang kembali sehingga para orangtua mempunyai alasan untuk menerapkan budaya bercerita atau berdongeng kepada anak-anak.

Dari paparan di atas, budaya bercerita di Pandean juga tidak lepas dari peran orangtua yang sering membacakan cerita untuk anakanaknya. Baik di waktu sedang akan tidur ataupun di waktu senggang misalnya. Para orangtua di Pandean masih membudayakan bercerita kepada buah hati mereka karena menurut mereka dengan bercerita anak akan dapat mengambil pesan-pesan dan nilai moral yang terkandung dalam sebuah cerita sehingga anak dapat menerapkannya di lingkungan bermainnya.

Penelitian menunjukkan bahwa dari 36 responden hanya 26 responden yang membacakan cerita untuk anakanak mereka. Jadi, hanya 35\% para orangtua di Pandean yang membacakan cerita kepada anak-anaknya. Cerita yang dibacakan beragam baik itu cerita sejarah, cerita dongeng, legenda atau cerita persuasif yang mendorong anak untuk mau melakukan kebiasaan yang baik. Sedangkan dalam lembaga pendidikan seperti halnya di sekolah SD Pandean 01 juga terdapat budaya bercerita melalui mata pelajaran Bahasa Daerah karena disini tenaga pendidik menceritakan tentang sejarah Pandean untuk menanamkan nilai-nilai luhur yang ada dalam cerita sehingga menjadikan anak untuk mengenal dan memahami tentang daerah tempat tinggalnya.

\section{B. Saran}

Dari pembahasan pada bab-bab sebelumnya, saran yang dapat diberikan yaitu:

1. Bagi Orangtua

a) Sebaiknya, penanaman dini dimulai dari orangtua itu sendiri. Misalnya saat anak 
masih di dalam kandungan, cerita bisa dibacakan saat akan tidur agar merangsang otak bayi untuk mendengar dan belajar.

b) Orangtua juga harus pandaipandai membacakan cerita untuk anak agar mereka bisa mendengarkan secara langsung dari orangtua bukan dari media lain seperti televisi atau CD agar anak lebih mendengar nasihat orangtua dan menerapkan nilai luhur yang terdapat dalam cerita.

2. Bagi Masyarakat

a) Masyarakat agar lebih meningkatkan lagi kebiasaan "nyadran" di Pandean agar semua lapisan masyarakat lebih memahami dan mengerti tentang sejarah Pandean itu sendiri.

b) Masyarakat agar lebih dapat melestarikan tentang tradisi lisan tentang sejarah Pandean dari "sesepuh" desa agar tradisi

\section{Daftar Pustaka}

lisan itu tidak hilang untuk generasi yang selanjutnya.

3. Bagi Lembaga Pendidikan

a) Tenaga pendidik sebaiknya menanamkan pola strategi belajar mengajar dengan bercerita agar siswa lebih memperhatikan karena di dalam cerita mempunyai daya tarik untuk anak agar mau belajar.

b) Tenaga pendidik agar bisa menanamkan pendidikan karakter dalam proses belajar mengajar dengan bercerita.

4. Bagi Prodi Pendidikan Sejarah

a) Mahasiswa prodi sejarah harus dapat menjadikan bercerita sejarah sebagai icon dari jurusan pendidikan sejarah.

b) Prodi pendidikan sejarah dapat menjadikan mahasiswa sejarah yang

pandai bercerita dan menggunakan strategi bercerita dalam proses belajar mengajar.

Burhan Bungin. 2007. Penelitian Kualitatif : Komunikasi, Ekonomi, Kebijakan Publik, dan Ilmu Sosial Lainnya. Jakarta: Kencana Pranada Media Group.

Daymon dan Holloway. 2002. Metodemetode Riset Kualitatif dalam Public Relations \& Marketing 
Communication. Terjemahan oleh Cahya Wiratama. 2008. Yogyakarta: Bentang.

Doni Koesoema A. 2007. Pendidikan Karakter: Strategi Mendidik Anak di Jaman Global. Jakarta: PT.Grasindo.

Dudung Abdurrahman. 2007. Metode Penelitian Sejarah. Yogyakarta: Ar-Ruzz Media.

Gottshalk, Louis. 1969. Mengerti Sejarah. Terjemahan oleh Nugroho Susanto. $1985 . \quad$ Jakarta: Universitas Indonesia (UIPress).

John, J. 2007. 26 Keys of Happiness: 26 Rahasia Menemukan Kebahagiaan dan Menikmati Hidup. Terjemahan oleh Indah Fitria. 2007. Jakarta: Raih Asa Sukses.

Laboratorium Pancasila IKIP Malang. 1991. Pendidikan Pancasila di Perguruan Tinggi. Malang: IKIP Malang.

Mardalis. 2007. Metode Penelitian: Suatu Pendekatan Proposal. Jakarta: Bumi Aksara.

Mohammad Ali, R. 2005. Pengantar Ilmu Sejarah Indonesia. Yogyakarta: LKiS.
Nasution, S. 2004. Metode Research (Penelitian Ilmiah). Jakarta: Bumi Aksara.

Nurul Zuriah. 2007. Pendidikan Moral dan Budi Pekerti dalam Perspektif Perubahan. Jakarta: Bumi Aksara.

Pawito. 2007. Penelitian Komunikasi Kualitatif. Yogyakarta: LKiS.

Roosseno. 2008. Jembatan dan Menjembatani. Jakarta: Yayasan Obor Indonesia.

Sofjan, Sonny B. 2009. Quantum Resign. Jakarta: PT Elex Media Komputindo.

Sugiyono. 2007. Metode Penelitian Kuantitatif, Kualitatif dan $R \& D$. Bandung: Alfabeta.

Tadkiroatun Musfiroh. 2011. Strategi Bercerita Cerita Sejarah. Agastya, 1(01): 45-48.

Tim Pengembang Ilmu Pendidikan UPI. 2007. Ilmu dan Aplikasi Pendidikan. Bandung: PT. Imperial Bhakti Utama.

Wiwit Wahyuning. 2003. Mengkomunikasikan Moral kepada Anak. Jakarta: PT. Elex Media Komputindo. 